\title{
Neuropeptide Y Receptor Type 2
}

National Cancer Institute

\section{Source}

National Cancer Institute. Neuropeptide Y Receptor Type 2. NCI Thesaurus. Code C105410.

Neuropeptide $Y$ receptor type 2 (381 aa, $\sim 43 \mathrm{kDa}$ ) is encoded by the human NPY2R gene. This protein plays a role in diverse physiological functions as a receptor for neuropeptide $\mathrm{Y}$. 